\title{
Model-Based Analysis of Changes in the Morphological Characteristics of Moscow Students for the Last Two Decades
}

\author{
Marina A. Negasheva, Sofya N. Zimina, Irina M. Sineva, Elena Z. Godina \\ Department of Anthropology, Biological Faculty, Lomonosov Moscow State University, Moscow, Russia
}

\begin{abstract}
A B S T R A C T
The aim of the paper is to develop a model of changes in morphological characteristics of young males and females body structure at the beginning of the $21^{\text {st }}$ century. For this purpose the results of Moscow students'annual screenings from 2000 to 2018 were analyzed (total number of 17-18-year-olds - 6,433 individuals). As a result, five factors describing the trends of changes were revealed and further analysis demonstrated variants of their values over time. An original model was developed, which reflected real morphological transformations in the body parameters of the young generation for the last 20 years. For both sex groups a trend towards macrosomia (gr. macros - big, soma-body) was revealed. For the boys some increase in linear traits was found with a decrease in muscularity. In girls, parabolic association between athletic characteristics and the year of investigation was found: the decrease in muscularity for the first decade, and its increase for the second one.
\end{abstract}

Key words: human morphology, body build, subcutaneous fat layer, Moscow students, model of secular changes

\section{Introduction}

In many studies of human morphological characteristics it has been shown that even for a short period of time in a relatively stable and homogenous group significant changes could occur ${ }^{1-3}$. Moreover, the pattern and direction of those changes are defined by an integral impact of different factors, such as ecological ones, changes in nutrition or mode of living, socioeconomic factors etc. ${ }^{4-6}$. In the recent decade's one of the most urgent research problems deals with the changes in adiposity as the global process of overweight and obesity is taking place all over the world at the end of the $20^{\text {th }}$ - the beginning of the $21^{\text {st }}$ century. Some authors call this trend "the obesity epidemic", which applies not only to adult people but also to children and youth ${ }^{3,7}$. For this reason, it is important to develop an integrated approach to the study of secular changes in morphological characteristics of the human body.

The aim of the present study is to develop a model of changes in morphological characteristics of Moscow students' body structure for the last two decades based on Moscow population data.

\section{Methods}

Data of the annual anthropological screenings of the first-year students enrolled to Lomonosov Moscow State University from 2000 to 2018 were used for the analysis. The total number of the subjects is 6,433 , with 2,999 males and 3,434 females, 17-18-year old. By their nationality all of the participants were Russians, born and permanently living in Moscow. The program included a large set of morphological measurements: height and weight, linear and transversal skeletal characteristics, circumferences and skinfolds on trunk and extremities. In addition, some indices were calculated for each individual: those characterizing body proportions, overweight etc., as well as body mass components (Matiegka's equations), and percentage of fat mass according to Slaughter's equations. All of the materials were collected in accordance with the bioethical procedure (signed consent protocols and data depersonification).

Modeling of morphological changes was carried out in three stages. For the first step, the whole set of somatic traits and indices was divided into subsets, which described different patterns of human body variability. To isolate those subsets correlation matrices were used be- 
tween all of the studied somatometric characteristics in both male and female groups. Pearson's correlation coefficients were calculated with the significance level $\mathrm{p}<0.05$.

At the second stage of modeling Principal Axis Factoring was used, which is considered the most effective for the analysis of multivariate traits structure with nonnormal distribution ${ }^{8,9}$. New variables were obtained, which reflected general patterns of variations in morphological subsets.

The next step aimed to study the changes of those variables in time - from the year 2000 to 2018. In addition to one-way ANOVA, the significance of the presence of the trend between 5-year intervals (2000-04; 2005-09 etc. - years of investigation) was evaluated, and pairwise comparison of means with Tukey's post-hoc test for the evaluation of significance level was applied. All of the above calculations were performed with the software STATISTICA 13.0 (Stat. Soft, Inc. 1984-2018).

\section{Results}

Correlation analysis performed separately for males and females allowed to choose those traits which were closely interconnected and identified the subsets of morphological traits. Three of such subsets were isolated: 1) vertical traits associated with linear skeletal development (length); 2) traits associated with transversal skeletal development (width) - biacromial and biiliac diameters, transversal and sagittal chest diameters, epiphyseal transverse diameters of the distal parts of long bones, bone mass; 3) traits associated with the development of muscular and fat mass - weight, Body Mass Index (BMI), absolute and relative (\%) muscular and fat mass evaluated with Slaughter's equations, body circumferences and thickness of skinfolds on the trunk and extremities. In both sex groups the structure of traits within the complex was similar. Results for a number of factor analyses in different subsets of morphological traits, as well as correlation coefficients between the factors (new integral variables) and the year of investigation, are given in Table 1. Five factors describing the intragroup variations of body build were determined: within the trait complexes: macrosomia indicator (general corpulence: increase in BMI and adiposity), athletic indicator (proportion of muscle and fat components of body mass), linear skeletal development (tall stature, relatively long legs), transversal skeletal development and chest shape.

In the last stage of the study, the graphs modeling patterns of changes in morphological characteristics of Moscow young males and females for the last two decades were constructed (Figures 1-2).

In both sex groups for the 2000-2018 time period steady statistically significant secular trends towards macrosomia were revealed. Total body dimensions increased both in males and females at the beginning of the $21^{\text {st }}$ century, as well as mean values of trunk and extremities circumferences, adiposity characteristics. These results coincide with

TABLE 1

RESULTS OF THE SERIES OF FACTOR ANALYSES IN THE SETS OF MORPHOLOGICAL CHARACTERISTICS AND THE ASSOCIATIONS BETWEEN INDIVIDUAL FACTOR VALUES AND THE YEAR OF INVESTIGATION (2000-2018)

\begin{tabular}{|c|c|c|c|c|c|c|c|}
\hline $\begin{array}{l}\text { Traits included in } \\
\text { the analysis }\end{array}$ & $\begin{array}{l}\text { Factors describing } \\
\text { morphological } \\
\text { variations }\end{array}$ & Sex & $\begin{array}{l}\text { \% of } \\
\text { described } \\
\text { intragroup } \\
\text { variability }\end{array}$ & $\begin{array}{l}r \text { - correlation } \\
\text { coefficient with } \\
\text { the year of } \\
\text { investigation }\end{array}$ & $\begin{array}{l}\mathrm{b}-\text { coefficient } \\
\text { of slope angle } \\
\text { in the regres- } \\
\text { sion equation }\end{array}$ & $\mathrm{p}$ & $\begin{array}{l}\text { Morphological interpreta- } \\
\text { tion (secular changes) }\end{array}$ \\
\hline \multirow{5}{*}{$\begin{array}{l}7 \text { Circumferences, } \\
6 \text { skinfolds, } \\
\text { weight, BMI, } \\
\text { MM, FM, \% FM }\end{array}$} & \multirow{2}{*}{$\begin{array}{l}\text { Macrosomia } \\
\text { indicator }\end{array}$} & 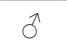 & $69.40 \%$ & 0.151 & 0.068 & 0.000 & \multirow[t]{2}{*}{ Increase in macrosomia } \\
\hline & & q & $63.50 \%$ & 0.102 & 0.021 & 0.000 & \\
\hline & \multirow[t]{3}{*}{ Athletic indicator } & $\hat{\sigma}$ & $11.60 \%$ & -0.115 & -0.112 & 0.000 & $\begin{array}{l}\text { Decrease in athletic } \\
\text { parameters }\end{array}$ \\
\hline & & \multirow[t]{2}{*}{ q } & \multirow[t]{2}{*}{$9.40 \%$} & \multirow[t]{2}{*}{0.209} & -31.70 & 0.000 & \multirow{2}{*}{$\begin{array}{c}\text { Parabolic association with } \\
\text { the year of investigation, } \\
\text { decrease at the beginning } \\
\text { and increase at the final } \\
\text { stage of the investigated } \\
\text { period }\end{array}$} \\
\hline & & & & & 0.079 & 0.000 & \\
\hline \multirow{2}{*}{$\begin{array}{l}\text { Linear skeletal } \\
\text { dimensions, BM, } \\
\text { Leg length/ } \\
\text { Height }\end{array}$} & \multirow{2}{*}{$\begin{array}{l}\text { Linear skeletal } \\
\text { development }\end{array}$} & $\hat{\sigma}$ & $56.30 \%$ & 0.048 & 0.017 & 0.011 & \multirow{2}{*}{$\begin{array}{c}\text { Slight increase with time } \\
\text { Non-significant }\end{array}$} \\
\hline & & q & $51.70 \%$ & 0.025 & -0.005 & 0.166 & \\
\hline \multirow{4}{*}{$\begin{array}{l}\text { Transversal and } \\
\text { linear skeletal } \\
\text { development, BM }\end{array}$} & \multirow{2}{*}{$\begin{array}{c}\text { Transversal skeletal } \\
\text { development }\end{array}$} & $\hat{\sigma}$ & $34.10 \%$ & -0.002 & -0.013 & 0.674 & \multirow[t]{2}{*}{ Non-significant } \\
\hline & & q & $34.80 \%$ & -0.008 & -0.001 & 0.661 & \\
\hline & \multirow[t]{2}{*}{ Chest shape } & 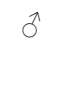 & $12.30 \%$ & 0.076 & 0.029 & 0.000 & $\begin{array}{l}\text { Decrease in relative chest } \\
\text { breadth }\end{array}$ \\
\hline & & 우 & - & & & & - \\
\hline
\end{tabular}

BMI - body mass index (weight, kg/height², m); BM, MM and FM - bone mass, muscle mass and fat mass correspondingly. 
Males

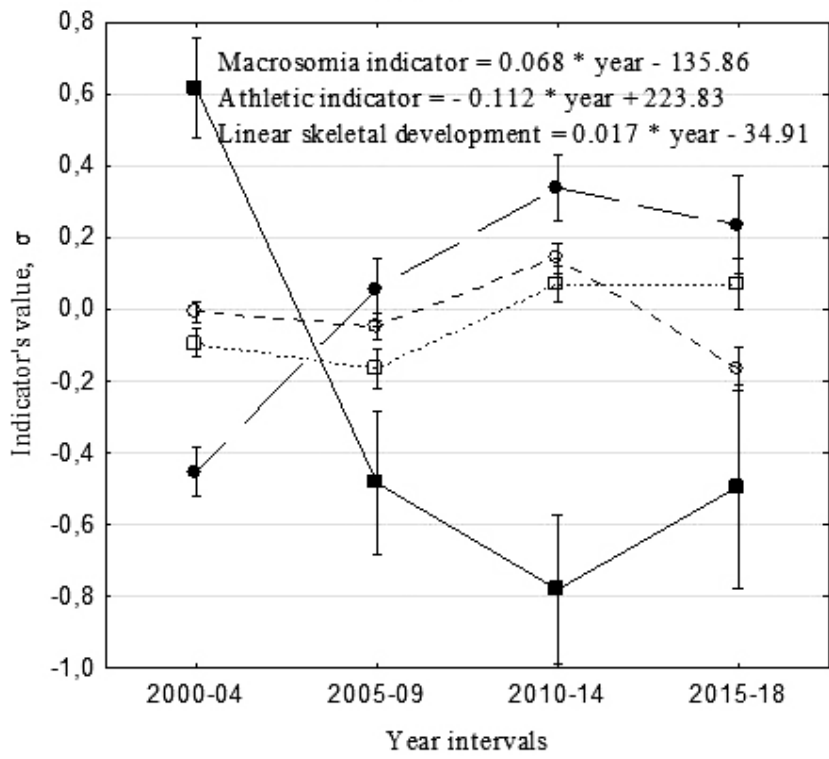

Females

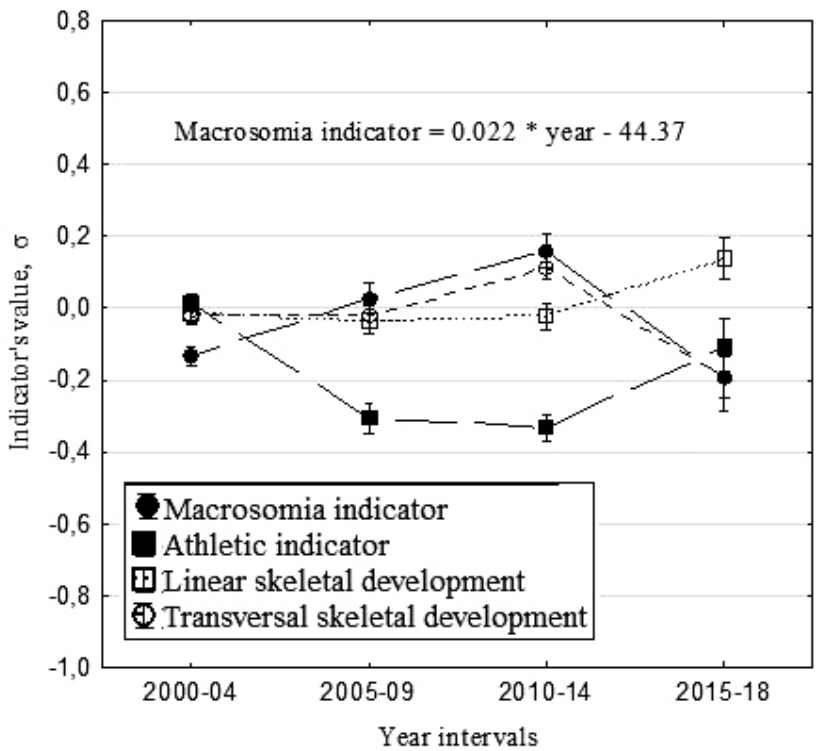

Fig. 1. Secular changes of the factors (integral indices of morphological parameters variations) in 5-year groups. Means and the range $M \pm m$ are indicated. Statistically significant regression equations with the year of investigation are given.

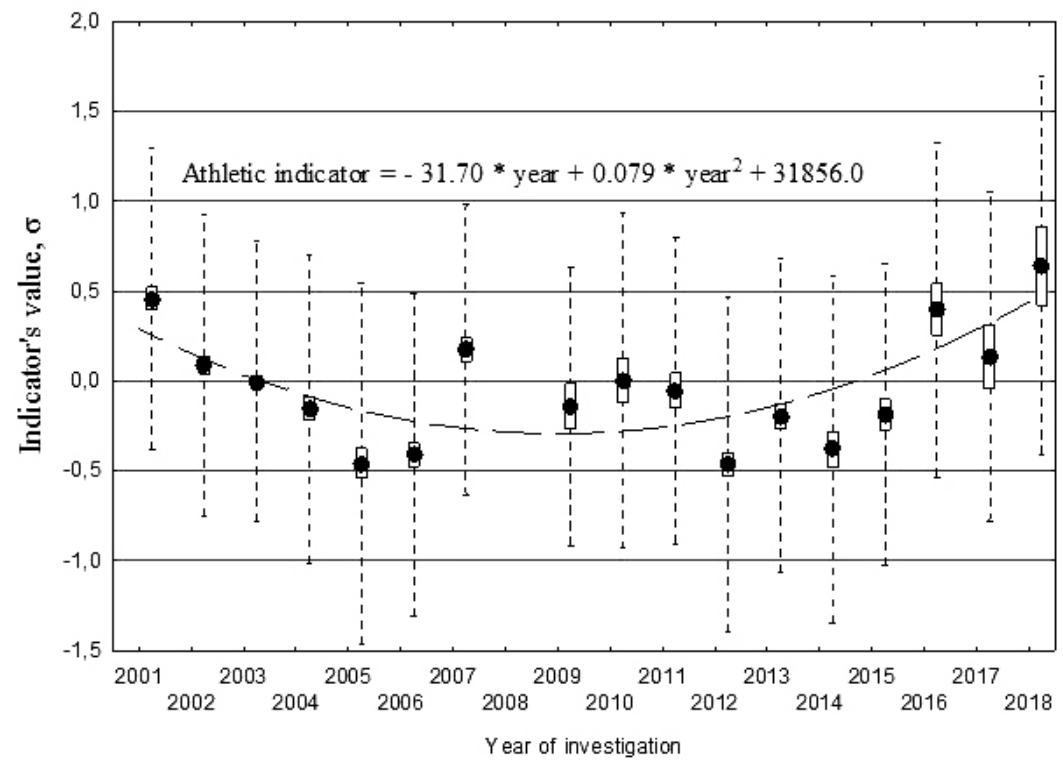

Fig. 2. Secular changes in athletic indicator of young females. For each year of investigation mean values of the factor are shown within the range $M \pm m$ and $M \pm \sigma$; parabolic regression line is given.

the global trends ${ }^{2-4}$ and those described for Russia ${ }^{10-12}$ of BMI increase and other characteristics associated with it. For the young males a slight secular increase in linear skeletal traits was also demonstrated, as well as the decrease in the athletic indicator (Figure 1), which reflects a decrease in muscle mass and parallel increase of fat component. In the female group statistically significant parabolic association of the athletic indicator with the year of investigation was found (Figure 2). While in the first decade a decrease of this index was found (a decrease of muscle mass with parallel increase in fat component), in the second decade - after 2010 - it started growing which demonstrates the improvement of physical development in modern young females. It is possible to suggest that the reason of such variations is the pressure of sociocultural stereotypes, of a certain standardized canon of women's physical attractiveness, widely spread in mass media, cultivation of the ideas that success in life depends on physical appearance ${ }^{13}$. These viewpoints exert much stronger impact on the female part of the population, especially on girls and young women, who aspire to have a slimmer shape and ideally build figure according to some beauty stereotypes ${ }^{11}$. 


\section{Conclusion}

Based on statistically representative data (more than 6,400 individuals under study) new results were obtained on changes in body dimensions of modern young people at the beginning of the $21^{\text {st }}$ century. An original model is presented, which reflects the pattern of changes in a large number of morphological characteristics of body build in young males and females for the last 20 years. For both sexes a steady trend towards macrosomia was found (an increase in total body dimensions and adiposity characteristics). For the males a slight increase in linear skeletal dimensions and a decrease in athletic indicator were found. For the females, a parabolic connection between the athletic indicator and the year of investigation was dem- onstrated for the first time: a negative association (decrease) in physical status in the first decade of the $21^{\text {st }}$ century (2000-2009), and an improvement of physical development in the latest decade (2010-2018).

\section{Acknowledgements}

This research was supported by RFBR grant N 1809-00290 "Biological and social factors of microevolutionary changes of the morphofunctional status and level of gender dimorphism in modern populations" (MAN, SNZ, IMS) and by Moscow State University Grant for Leading Scientific Schools "Depository of the Living Systems" in frame of the MSU Development Program (EZG).

\section{R E F E R E N C E S}

1. DE ONIS M, LOBSTEIN T, Int J Pediatr Obes 5 (2010) 458-460. doi: 10.3109/17477161003615583. - 2. HERMANUSSEN M. Auxology. Studying Human Growth and Development (Schweizerbart, Stuttgart, 2013). - 3. NCD RISK FACTOR COLLABORATION, Lancet, 387 (2016) 1377. doi: 10.1016/S0140-6736(16)00618-8. - 4. BOGIN B, Secular changes in childhood, adolescent and adult stature. Recent advances in growth research: nutritional, molecular and endocrine perspectives. In: Nestlé Nutr Inst Workshop (Basel, 2013). - 5 . GRASGRUBER P, SEBERA M, HRAZDÍRA E, CACEK J, KALINA T, Econ Hum Biol, 21 (2016) 172. doi: 10.1016/j.ehb.2016.01.005. — 6. LITVIN FB, DOROFEEV VV, ZHIGALO VYA, BYKOVA IV, NIKITYUK DB, KLOCHKOVA SV, Gigiena i sanitaria, 98 (2019) 388. - 7. OLDS T, MAHER C, ZUMIN S, PÉNEAU S, LIORET S, CASTETBON K, BELLISLE, DE WILDE J, HOHEPA M, MADDISON R, LISSNER L,
SJÖBERG A, ZIMMERMANN M, AEBERLI I, OGDEN C, FLEGAL K, SUMMERBELL C, Int J Pediatr Obes, 6 (2011) 342. doi:10.5167/ uzh-57722. - 8. COSTELLO AB, OSBORNE JW, Practical Assessment, Research \& Evaluation, 10 (2005) 2. doi:10.7275/jyj1-4868. — 9. DE WINTER JCF, DODOU D, J Appl Stat, 39 (2011) 695. doi 10.1080/02664763.2011.610445 - 10. FEDOTOVA TK, GORBACHEVA AK, Archaeology, Ethnology and Anthropology of Eurasia, 47 (2019) 149. doi: 10.17746/1563-0110.2019.47.3.145-157 — 11. GODINA EZ, Anthropol Anz, 68 (2011) 367. doi: 10.1127/0003-5548/2011/0156. — 12. NEGASHEVA MA, ZIMINA SN, KHAFIZOVA AA, SIRAZETDINOV RE, SINEVA IM, Moscow Univ Biol Sci Bull, 75 (2020) 15. - 13. KEEL PK, BAXTER MG, HEATHERTON TF, JOINER JR TE, J Abnorm Psychol, 116 (2007) 422. doi: 10.1037/0021-843X.116.2.422.

\section{E.Z. Godina}

Department of Anthropology, Biological Faculty, Lomonosov Moscow State University, Lenin Hills, 119234, Moscow, Russia

e-mail: egodina11@gmail.com

\section{MODEL ANALIZE MORFOLOŠKIH PROMJENA MOSKOVSKIH STUDENATA U ZADNJIH 20 GODINA}

\section{S A Ž E T A K}

Cilj ovog rada je razvoj modela promjena u morfološkim obilježjima tjelesne strukture djevojaka i mladića na početku 21. stoljeća. U tu svrhu analizirani su rezultati godišnjih mjerenja moskovskih studenata od 2000. do 2018. godine (ukupno 6.433 osobe u dobi od 17-18 godina). Analizom je dobiveno pet faktora koji opisuju trendove promjena a daljnja analiza je pokazala varijabilnost vrijednosti tijekom vremena. Razvijen je originalan model koji odražava stvarne tjelesne morfološke promjene mlade generacije u posljednjih 20 godina. U oba spola uočen je trend makrosomije (grč. makrós: velik, sôma: tijelo). U mladića opaženo je povećanje linearnih obilježja i smanjenje mišićnog tkiva. U djevojaka je utvrđena parabolična povezanost između atletskih karakteristika i godine ispitivanja: u prvom desetljeću došlo je do smanjenja mišićnog tkiva, a u drugom do njegovog povećanja. 